\title{
Smallholder Farmers' Perception and Adaptation to Climate Change in Kurmuk District, Ethiopia
}

\author{
Asaye Damera Ayansa ${ }^{1}$, Amsalu Bedemo $^{2}, \&$ Gemechu Ordofa Jara ${ }^{3}$ \\ ${ }^{1}$ Plan International, Addis Ababa, Ethiopia \\ ${ }^{2}$ Ethiopian Civil Service University, Addis Ababa, Ethiopia \\ ${ }^{3}$ Independent consultant, Addis Ababa, Ethiopia \\ Correspondence: Gemechu Ordofa Jara, Independent consultant, Addis Ababa, Ethiopia.
}

Received: September 11, 2021

doi:10.11114/aef.v8i5.5362
Accepted: September 23, $2021 \quad$ Available online: September 24, 2021

URL: https://doi.org/10.11114/aef.v8i5.5362

\begin{abstract}
Ethiopia is among the countries experiencing frequent drought and highly vulnerable to climate change associated impacts. Adaptation to climate change impacts are key element for sustainable development of economy. The objective of the study was analysis determinates of smallholder farmer's climate change perception and adaptation options in Kurmuk district. For the study both primary and secondary data sources were employed. The primary data collected from 160 randomly selected sample households. The binary logit and multinomial logit model were employed to identify the factor that determines smallholder farmers' climate change perception and adaptation strategies respectively. Results revealed that sex, extension service, credit access, climate information and distance from market are significantly affects smallholder farmers' perception to climate change in kurmuk district, While, sex, education, cultivated land, access to credit services, climate information, access to market, extension service, distance from farm, off-farm income and on-farm income are found statistically significant affected adaptation options of smallholder farmers. Therefore, strengthening extension services, access credit services, disseminating climate and market information, diversification of farmer's income are among the recommendable mechanisms to advance their perception and adaptation to climate change.
\end{abstract}

Keywords: climate change, perception, adaptation, multinomial logit

\section{Introduction}

Climate change is the current most serious challenging and cross cutting issue over the world which will be able to retard the acceleration of sustainable development goal.The climate variability and extremes is a key driver behind the recent rise in global hunger and one of the leading causes of severe food crises (Molotoks et al., 2018).climate change affecting agriculture and food security and challenge of ending hunger and malnutrition (El Bilali et.al., 2020). Low income producers and consumers of food in Africa are more vulnerable to climate change, owing to their comparatively limited ability to invest in more adapted institutions and technologies under increasing climatic risks (Zougmoré et.al., 2021).

Ethiopian agriculture system is climate-sensitive and due low adaptive capacity of the subsistence farmers (Asfaw et.al. 2021). Climate change impact adaption is key element for sustainable and transformational development of all sectors of economy and in particular agriculture sector. Ethiopia is among the countries experiencing frequent drought and highly vulnerable to climate change associated impacts Gebreegziabher et al. (2012). The projection of the mean annual temperature will increase in the range $0.9-1.1^{\circ} \mathrm{c}$ by $2030,1.7-2.1^{\circ} \mathrm{c}$ by $2050 \& 2.7-3.4^{\circ} \mathrm{c}$ by 2080 as compared to the normal $1961-1990$. The cause for climate variability and climate change due to the country is dependence on rain-fed agriculture under-development of water resources, low health service coverage, a high population growth rate, low economic development, inadequate road infrastructure in drought prone areas, weak institutional structures, and lack of awareness and relatively low adaptive capacity to deal with these expected changes (Bigger and Webber, 2021).

Benishangul Gumuz region is among the developing regions of Ethiopia which is highly depending on natural resource which contribute for drivers of climate change. According to the regional Food Security Disaster Risk Prevention and Preparedness office annual report (2016), the occurrence of Elino at Kurmuk, Sherkole , Guba and Menge districts. In 
the Kurmuk district out of the 16 kebeles in district in 12 kebeles, were affected and 1,135.25 hectare of land cultivated crops damaged and about 16,130 populations were relief assisted. The recover and cope up strategies of smallholders farmers from climate change impacts is important understand the effort of smallholder farmer's to reduce these problems and improve effort to strength smallholder farmers' adaptation to climate change to enhance the resilience of agricultural sectors. Therefore, study aim was to identify smallholder farmers' adaptation strategies to climate change and variability's in Kurmuk district.

\section{Empirical Review and Model Specification}

According to the United Nations' Intergovernmental Panel on Climate Change (IPCC) (1994) responses to climate change can be grouped into two categories: mitigation and adaptation. Mitigation embraces responses that deal with the cause of climate change rather than the impact climate change has on a given area (Carter et al., 1996). Responses classified as adaptations deal with the impact of climate change rather than the cause. One of the main objectives of this study was to identify smallholder farmers' adaptation strategies to climate change and variability's. Previous studies in Africa have used various empirical methods to analyze the perception of climate change variability, determinants of adaptations to climate change and choice of adaptation strategies. Depending on the assumed distribution that the random term follows several qualitative choices, models such as linear probability, logit/probit, model could be used. For instance, a probit model (Bryan et al.., 2009) Multinomial logit model (Belay et al.2017, Atinkut and Mebrat, 2016, Deressa et al.,2009, Aemro et al.,2012, Zizinga et.al., 2017 and Yenealem et al., 2013 etc ...),multivariate probit(Arun and Yeo, 2019, Tesfaye and Seifu,2016, Sani et.al 2016, Feleke et.al.,2016, Ojo, and Baiyegunhi,2018 etc...), ordered probit (Ndambiri et al., 2012),Heckman model(Tesso et al.,2012, Asayehegn et.al.,2017 Ndambiri et al.(2013).

Some recent empirical studies of technology adoption and climate adaptation decisions assume that farmers consider a set possible practices and choose the practice that maximizes expected utility (Kassie et al., 2009).The theoretical framework draws on adaption options based on the random utility model as specified by (Green, 2003). The selection of whether or not to use any adaptation option could fall under the general framework of its value and production improvement capacity. Assume a rational farmer who pursues to improve agricultural productions over a specific time and must choose among a set of ' $j$ ' adaptation options. Hence, the farmer ' $i$ ' decides to use ' $j$ ' adaptation options if the perceived benefit from option ' $\mathrm{j}$ ' is greater than the utility from other options $\mathrm{k}$ stated as:

$$
\mathrm{U}_{\mathrm{ij}}(1)\left(\beta^{\prime} j X i+\varepsilon j\right)>\mathrm{U}_{\mathrm{ik}}\left(\beta^{\prime} k X i+\varepsilon k\right), k \# j,
$$

Where $\mathrm{U}_{\mathrm{ij}}$ and $\mathrm{U}_{\mathrm{ik}}$ are the perceived value by farmer i of adaptation options $j$ and $k$, respectively; $X i$ is a vector of explanatory variables that influence the choice of the adaptation option: $\beta j$ and $\beta k$ are parameters to be estimated and $\varepsilon j$ and $\varepsilon k$ are the error terms. Under the revealed preference assumptions that the farmer practices an adaptation option that generates net benefits and doesn't practice an adaptation option otherwise, we can relate the observable climate change adaption choice of practices to the unobservable continuous net gain variable as $Y i j=1$ if $U i j>$ 0 and $Y i j=0$ if $U i j$

$$
\begin{aligned}
& P\left(\frac{Y-1}{X}\right)=P\left(\frac{U i j>U i k}{X}\right) \\
= & P \beta^{\prime} j X i+\varepsilon j-\beta^{\prime} k X i-\varepsilon k>0 / X \\
= & \beta^{\prime} j-\beta^{\prime} k X i+\varepsilon j-\varepsilon k>0 / X \\
= & P\left(\beta * X i+\varepsilon *>\frac{0}{X}\right)=F(\beta * X i),
\end{aligned}
$$

Where $\varepsilon^{*}=$ a random disturbance term, $\beta *=$ a vector of unknown parameters that can be interpreted as the net influence of the vector of explanatory variables influencing adaptation, and $\mathrm{F}(\beta * \mathrm{Xi})=$ the cumulative distribution of $\varepsilon *$ evaluated at $\beta * X i . \quad$ In this study, we assumed that several adaptation choices and the appropriate economic model would be either a multinomial logit/ probit $(\mathrm{MNL} / \mathrm{p})$ regression model. Both models estimate the effect of explanatory variables on a dependent variable involving multiple choices with unordered response categories (Omer, 2019). The MNL specification was adapted to model climate change adaptation behavior of farmers involving in Kurmuk district 
dependent variables with multiple choices. Thus, the probability that household ' $i$ ' with characteristics ' $X$ ' choose adaptation option ' $\mathrm{j}$ ' was specified as:

$$
\begin{gathered}
P_{i j}=\operatorname{prob}(Y=1) \\
=\ell X^{\prime} \beta 1+j \mathrm{j}=1 \ell X^{\prime} \beta, j=1 \ldots
\end{gathered}
$$

Where $\beta$ is a vector of parameters that satisfy $\ln \left(\mathrm{P}_{\mathrm{ij}} / \mathrm{Pik}\right)=\mathrm{X}^{\prime}(\beta \mathrm{j}-\beta \mathrm{k})$.Undesirable and consistent parameter estimates of the MNL model require the assumption of independences of irrelevant alternatives (IIA) to hold. Differentiating the above equation with respect to each explanatory variable provides marginal effects of the explanatory variables given as:

$$
\frac{\partial P j}{\partial X k}=p_{i}\left(B_{i j}-\sum_{j=1}^{j-1} p_{i} B_{i j}\right)
$$

Where, $\mathrm{i}=1,2, \ldots . \mathrm{N}$ are the individual farmer and $\mathrm{j}=1,2, \ldots . \mathrm{J}$ are the alternative adaptation methods, $X_{i j}$ vector are factors that influence farmers' choice and adaptation method to climate change and $\varepsilon_{i j}$ is the random error term /disturbance term. Farmers perceive climate change in different ways. For example, farmers perceive climate change through drought, floods, off seasonal rainfall (erratic rain fall), too much rainfall, too little rainfall, higher temperature, frost, high winds, frequent animal disease, frequent crop disease and frequent human disease. Farmer's perception to climate changes a dichotomous form which is " 1 " if they perceive " 0 " otherwise. According to Gujarat (1995) the binary logit distribution function can thus be specified as;

$$
\begin{gathered}
\mathrm{pi}=\frac{1}{1+\mathrm{e}^{-\mathrm{zi}}} \\
\text { Where } \mathrm{p}_{\mathrm{i}}=\text { probability of success } \\
\mathrm{e}=\text { Base of natural logarithms } \\
\mathrm{Zi}=\operatorname{explanatory} \text { variables } \\
\mathrm{Zi}=\beta *+\beta 1 \mathrm{x} 1+\beta 2 \times 2 \ldots \ldots .+\beta \mathrm{m} \times \mathrm{xm}
\end{gathered}
$$

The odds ratio of the probability farmers to perceive and the probability not perceiving $(1-$ pi) represented as

$$
\frac{p i}{1-p i}=\frac{1+e^{z i}}{1+e^{-z i}}=\mathrm{e}^{\mathrm{z}}
$$

Taking the natural logarithms of the odds ratio of equation (4) will result in what is known as the log model as indicated below

$$
\operatorname{In}\left(\frac{p i}{1-p i=}\right)=\operatorname{In}\left(e^{\beta+} \sum_{i=0}^{m}(\beta i x i /)=Z i\right)
$$

The final logit model has the form $\quad \mathrm{Z}_{\mathrm{i}=} \beta *_{+} \sum \beta \mathrm{ixi}+\mathrm{ui}$

\section{Methods}

\subsection{Study Area}

This study was conducted in Kurmuk district, which is one of district in Asossa zone Benshangul Gumuz regional state. The district is characterized by two livelihood zones dry kolla and wet kolla. The District is characterized by a crop-livestock mixed farming. Farmers keep a significant number of cattle, sheep, donkey, and got for various purposes. Crops widely produced in the area include maize and sorghum. Moreover, vegetables and root crops produced in the area include onions, potato, tomato, pepper, cabbage, and sweet potato.The livelihoods of the district are highly vulnerable and affected by climate change variability. 


\subsection{Sampling Techniques and Sample Size Determination}

A multistage sampling procedure was used to sample smallholder farmers from Kurmuk district. Atotal of 60 farmers from three kebeles (Dul-Hode, Agubela and Famatsare) of Kurmuk district were selected and interviewed on smallholder farmers' adaptation strategies to climate change and variability's, socio-demographic and institutional characteristics. The Yamane (1967) formula was used for population known and the district population (smallholder farmers) were almost homogenous as follows:

$$
\begin{gathered}
n=\frac{N}{1+N(e)^{2}}=\frac{862}{1+862\left(0.07^{2}\right)} \sim 165 \\
\text { Where, } \mathrm{n}=\text { sample size, } \\
\mathrm{N}=\text { Population size and } \\
\mathrm{e}=\text { level of precision assumed } 7 \%
\end{gathered}
$$

Table 1. Sampled distribution of smallholder farmers

\begin{tabular}{llll}
\hline No & Kebeles & Total numbers household's & sampled household's \\
\hline 1 & Dul-Hode & 299 & 56 \\
2 & Agubela & 387 & 72 \\
3 & Famatsare & 176 & 32 \\
& Total & 862 & 160 \\
\hline
\end{tabular}

Source: Kurmuk Office of Agriculture 2020.

\subsection{Data Types, Sources and Method of Data Collection}

Both primary and secondary data was utilized in this study. The primary data was gathered from sample household heads using structured questionnaire through face-to-face interviews in January 2020. Questionnaire and checklist were prepared and pretested before data collection. Key informants drawn from development agents (DAs) and model farmers were interviewed for in-depth qualitative information and triangulating data from the household survey.

\section{Result and Discussions}

\subsection{Socio Demographic Characteristics of Households}

Out 160 households about $64 \%$ of households perceived climate change and have adopted various climate change adaption strategies'. Out of 160 households interviewed about $84 \%$ were male head and $16 \%$ were female head. The average age for household was 40 years. The overall mean of family size of household was found to be 7 per household. The average education of household head was 4.5 years. The mean of cultivated land of household head was 2 hectors. The mean of distance from farm and distance from market for household head was 10 and 6 kilometres respectively. About $60 \%$ of households access to credit service are perceive the climate change, while about $90 \%$ of households who have access to climate change had perceived the climate changes and variability. About $83 \%$ of households whose have an access to extension service had perceive climate change. From 160 sampled households about $69 \%$ of households were perceived climate change and variability. The result of the study showed about $87 \%$ of household perceive climate variability through decrease in rain fall distribution, while, $95 \%$ perceive increase in temperature from year to year. The result of the study showed about $22 \%$ of believed that the cause of climate change and variability was human action on natural resources, about $8 \%$ believed that natural process, about $26 \%$ believed both of both human action and natural process. The result showed that respondent households on consequences of climate change. Among these, $65 \%$ of the respondents respond that reduced crop yield, $60 \%$ weeds and pests, $58 \%$ outbreak disease, $56 \%$ food shortage, $55 \%$ reduced water quality and size, $54 \%$ frequent crop disease and $54 \%$ respond livestock death observed due to climate change.

\subsection{Determinants of Smallholder Farmers' Perception to Climate Change}

A binary logit model employed for perception analysis using 12 explanatory variables. The model overall goodness of fit parameters predicted and chi-square tests show that the overall goodness of fit model was 160.69 and statistically significant at less than $1 \%$. This shows that jointly independent variables included in the logistic regression model. The pseudo -R2 values show that the independent variables included in the regression explain a significant proportion of the variability in the farmer likelihood to perceive climate change. Thus, pseudo - R $2=0.81$ shows that about $81 \%$ of the variation in the dependent variable was for the explanatory variables included in the model. 
Table 2. Determinants of smallholder farmers' perception to climate change

\begin{tabular}{|l|l|l|l|}
\hline Variables & Coefficient & Standard error & Marginal effect \\
\hline Constant & 4.139 & 18.098 & - \\
\hline Sex & $0.548 * * *$ & 2.638 & 0.275 \\
\hline Age & 0.67 & 0.264 & 0.001 \\
\hline Education & 0.385 & 0.376 & 0.020 \\
\hline Family size & -0.293 & -0.121 & 0.034 \\
\hline Cultivated land & 1.141 & 1.552 & 0.025 \\
\hline Access of credit service & $1.433^{* *}$ & 2.801 & 0.257 \\
\hline Climate information & $1.535^{* * *}$ & 3.055 & 0.556 \\
\hline Distance from farm & 5.022 & 1.647 & -0.013 \\
\hline Extension service & $1.320^{* *}$ & 2.903 & 0.057 \\
\hline Income from farming & 1.153 & -0.672 & 0.141 \\
\hline Income from off farming & 1.583 & -0.227 & 0.886 \\
\hline Distance market & $-0.093^{* *}$ & -0.223 & -1.12 \\
\hline Log likelihood & -19.02 & & \\
LR chi2(10) & 160.69 & & \\
Prob $>$ chi2 & 0.000 & & \\
Pseudo R2 & 0.81 & & \\
Number of observation & 160 & & \\
& $* * *, * *$ and $*$ significant at $1 \%, 5 \%$ and $10 \%$ & \\
& & & \\
\hline
\end{tabular}

Source: Model output, 2020

The study showed that climate information was positively and significant affects household's perception to climate change and variability. The marginal effect of the variable shows smallholder those have access to climate information are more likely to perceive climate change by $55.6 \%$ over those have no access to climate information. This finding is similar to the findings of Ndambiri et al.(2013) and Tesso et al.(2012) that access to climate information have a positive relationship with perception to climate change. Access to credit service had a positive relationship with household perception to climate change. Farmers those who have access credit more likely to perceive climate change by $25.7 \%$ over those have no credit access. This finding is supported by of Tesso et al.(2012).Sex of household head had a positively affects household perception to climate change. The marginal effect of the variable showed male headed households is more likely to perceive climate change by $27.5 \%$ than female headed. This finding is similar to the finding of Juana et al.(2013).

Distance from market negatively affects farmers' perception to climate change. The marginal effect result shows that one kilo meter increase in distance from market resulted in a likelihood of smallholder farmers' perceiving climate change is decrease by $1.2 \%$ keeping other factors constant. The finding supported Ndambiri e al.(2013)and Tesso et al.(2012).Access to extension service was positively affects household perception of climate change. The result of study shows those farmers have access to extension service more likely to perceive climate change by $5.7 \%$ over those have no access to extension service. This finding is similar to Ndambiri et al.(2013)and Tesso et al.(2012).

\subsection{Determinants of Smallholder Farmers'Adaptation Option to Climate Change}

In this section, the multinomial logit (MNL) model for adaptation choices to climate change adaption options in Kurmuk district was estimated by using the statistical software STATA version 14. The analysis was based on cross-sectional data collected from the rural households of Kurmuk district. Before initial runs of the model, the data were checked for the presence of any multicollinearity in the data set. Among the variables hypothesized to influence adaptation in the above section, these correlation coefficients which do not suggest the incidence of strong co-linearity were dropped from the model. The multinomial logit econometric model was preferred because there is no fears of adaptation categories are dependent of each other. Therefore the detail explanation based on the regression result presented as follows. The likelihood function for the multinomial logit model was significant Wald $\chi^{2}=127.469, \mathrm{P}<$ $0.0000)$, showing a strong explanatory power.

As shown in Table 5 below, the likelihood of taking adaptation practice found to be statistically significant for the factor variable of the sex of the household head at the $1 \%$ level of significance. The result of study shows being male head household leads to more crop diversification as an adaptation option than female head household. This finding is supported by Yenealem et al.(2013), Deressa et al.(2009), Aemro et al.(2012). Education level of household head had a positive association to improved crop and livestock production an adaptation option. The education level of household head increase household head motivates to prefer more adaptation options. Size of cultivated land owned household head statically significant to soil and water conservation practices positively. The households whose have more 
cultivated land had used soil and conservation practices as options to climate change adaption options. The finding supported Asfaw et al.(2019). Access to credit services significant affects all adaptation options positively.

Table 3. Determinants of smallholder farmers' adaptation option to climate change

\begin{tabular}{|c|c|c|c|c|c|c|c|c|}
\hline \multirow{2}{*}{$\begin{array}{l}\text { Variables } \\
\text { Variables }\end{array}$} & \multicolumn{2}{|c|}{ Crop diversification } & \multicolumn{2}{|c|}{$\begin{array}{l}\text { Improved crop and } \\
\text { livestock production }\end{array}$} & \multicolumn{2}{|c|}{$\begin{array}{l}\text { Soil and water conservation } \\
\text { practices }\end{array}$} & \multicolumn{2}{|c|}{ Tree plantation } \\
\hline & $\begin{array}{l}\text { Coefficien } \\
\text { ts }\end{array}$ & $\begin{array}{l}\text { Marginal } \\
\text { effect }\end{array}$ & $\begin{array}{l}\text { Coefficien } \\
\text { ts }\end{array}$ & $\begin{array}{l}\text { Marginal } \\
\text { effect }\end{array}$ & $\begin{array}{l}\text { Coefficien } \\
\text { ts }\end{array}$ & $\begin{array}{l}\text { Marginal } \\
\text { effect }\end{array}$ & $\begin{array}{l}\text { Coefficien } \\
\text { ts }\end{array}$ & $\begin{array}{l}\text { Marginal } \\
\text { effect }\end{array}$ \\
\hline Constant & -4.139 & - & 21.739 & - & -0.179 & - & 17.41 & - \\
\hline Male & 2.638 & $0.313^{*}$ & 2.297 & 0.08 & 1.478 & 0.0003 & 1.754 & 0.034 \\
\hline Age & 0.056 & 0.010 & -0.007 & -0.004 & 0.0002 & -0.004 & 0.049 & 0.003 \\
\hline $\begin{array}{l}\text { Education } \\
\text { of } \\
\text { household }\end{array}$ & 0.376 & 0.012 & 0.462 & 0.015 & 0.502 & $0.023^{*}$ & 0.467 & 0.018 \\
\hline $\begin{array}{l}\text { Family } \\
\text { size }\end{array}$ & -0.121 & -0.030 & 0.234 & 0.035 & -0.124 & -0.012 & -0.044 & -0.001 \\
\hline Cult & 1.552 & 0.104 & 1.063 & -0.027 & 2.299 & $0.150 * *$ & 1.462 & 0.027 \\
\hline $\begin{array}{l}\text { Access to } \\
\text { credit }\end{array}$ & 2.801 & $0.086^{*}$ & 3.710 & $0.137 * *$ & 3.885 & $0.184 * * *$ & 3.063 & $0.065^{* *}$ \\
\hline \begin{tabular}{l|l} 
Climate \\
informatio \\
$\mathrm{n}$
\end{tabular} & 3.056 & $0.350 * *$ & 1.810 & 0.001 & 2.178 & 0.044 & 2.557 & 0.084 \\
\hline $\begin{array}{l}\text { Market } \\
\text { access }\end{array}$ & 5.023 & $0.311 * * *$ & 3.941 & $0.001 * *$ & 5.92 & $0.264 * * *$ & 4.475 & $0.054 * * *$ \\
\hline $\begin{array}{l}\text { Access to } \\
\text { extension }\end{array}$ & 2.903 & $0.093 * *$ & 5.526 & $0.277 * * *$ & 3.73 & $0.115^{* *}$ & 3.935 & $0.132 * * *$ \\
\hline $\begin{array}{l}\text { Non- farm } \\
\text { income }\end{array}$ & -0.672 & -0.083 & -0.956 & -0.064 & -0.265 & 0.027 & -0.237 & 0.031 \\
\hline $\begin{array}{l}\text { Farm } \\
\text { income }\end{array}$ & -0.227 & 0.296 & -2.701 & -0.218 & -1.06 & -0.007 & -2.868 & $-0.26^{*}$ \\
\hline $\begin{array}{l}\text { Distance } \\
\text { from farm }\end{array}$ & -0.223 & 0.007 & -0.356 & -0.014 & -0.272 & -0.0048 & -0.477 & $-0.034 * *$ \\
\hline \multicolumn{3}{|l|}{$\begin{array}{l}\text { LR chi2 }(48) \\
\text { Prob }>\text { chi2 }\end{array}$} & \multicolumn{6}{|c|}{$\begin{array}{l}\text { Number of obs }=160 \\
* * *, * * \text { and } * \text { significant at } 1 \%, 5 \% \text { and } 10 \% \text { respectively }\end{array}$} \\
\hline
\end{tabular}

Source: model output, 2020

Households whose have access to climatic information diversify crop production to cope up the climate change variability. This finding is similar with the findings of Ndambiri et al.(2013), Deressa et al.(2009), Aemro et al.(2012) and Belay et al.(2017).Household whose have market access for input and output significantly affect crop diversification, improved livestock and crop production, soil and water conservation practices and tree plantation adaptation jointly. This finding supported Belay et al.(2017). Households whose have an access to credit service were adopt or more preference to use crop diversification, improved livestock and crop production, soil and water conservation practices and tree plantation jointly. This finding is similar to Deressa et al.(2009) and Aemro et al.(2013) Climate information significantly and positively affects household crop diversification.

Extension service affects adaptation crop diversification, improved livestock and crop production, soil and water conservation practices and tree plantation positively. Households those have access to extension service more probably prefer to use crop diversification, improved livestock and crop production, soil and water conservation practices and tree plantation as an adaptation options jointly. The finding is similar with Deressa et al.(2009), Aemro et al.(2012) and Bedeke et al.(2019).Off-farm income was significantly affects adaptation option of improved crop and livestock production and tree planation negatively. The households those participated in off-farm income less allocation labour, money and time to tree planation, improve crop and livestock production. This finding is similar to Deressa et al.(2009) and Aemro et al.(2012). Distance from farm was negatively affects household choice improved crop and livestock production and tree planation options. Households those have distance from their farm lands have less choose improved crop and livestock production and tree plantation as an adaptation option. The finding supported by Aemro et al.(2012). 


\section{Conclusion}

Ethiopia's vulnerability to climate change. Agriculture is the most susceptible sector to climate change related hazards. Adaptation to climate change impacts are key element for sustainable and transformational development of agriculture. This study investigated how smallholder farmers perceive climate change, what adaptation strategies they practice, and factors that influence their adaptation decisions. Both primary and secondary data were used for the study. The primary data collected from by using household survey from 160 randomly selected sample households. The logistic regression and multinomial logit model were employed to identify the factors that shape smallholder farmers' climate change perception and adaptation strategies respectively. Results revealed that sex, extension service, credit access, climate information and distance from market are significantly affects smallholder farmers' perception to climate change in kurmuk district. sex, education, cultivated land, credit access, climate information, market access, extension service, distance from farm, off-farm income and on-farm income are found statistically significant affected adaptation options of smallholder farmers. Furthermore, bout $69 \%$ of the respondent household perceive climate change and about $64 \%$ used adaptation option to climate change impacts. Therefore, strengthening extension services, access credit services, disseminating climate and market information, diversification of farmer's income are among the recommendable mechanisms to advance their perception and adaptation to climate change in the study area and other similar parts of the country.

\section{References}

Aemro, T., Jemma, H., \& Mengistu, K. (2012). Climate Change Adaptation Strategie s of Smallholder Farmers: The Case of Babilie District, East Harerghe Zone of Oromia Regional State of Ethiopia. Journal of Economics and Sustainable Development, 3(14), 1-12.

Arun, G. C., \& Yeo, J. H. (2019). Perception to adaptation of climate change in Nepal: An empirical analysis using multivariate probit model.

Asayehegn, K., Temple, L., Sanchez, B., \& Iglesias, A. (2017). Perception of climate change and farm level adaptation choices in central Kenya. Cahiers Agricultures, 26(2), 25003. https://doi.org/10.1051/cagri/2017007

Asfaw, A., Bantider, A., Simane, B., \& Hassen, A. (2021). Smallholder farmers' livelihood vulnerability to climate change-induced hazards: agroecology-based comparative analysis in Northcentral Ethiopia (Woleka Sub-basin). Heliyon, 7(4), e06761. https://doi.org/10.1016/j.heliyon.2021.e06761

Asfaw, A., Simane, B., Bantider, A., \& Hassen, A. (2019). Determinants in the adoption of climate change adaptation strategies: evidence from rainfed-dependent smallholder farmers in north-central Ethiopia (Woleka sub-basin). Environment, Development and Sustainability, 21(5), 2535-2565. https://doi.org/10.1007/s10668-018-0150-y

Atinkut, B., \& Mebrat, A. (2016). Determinants of farmers choice of adaptation to climate variability in Dera woreda, south Gondar zone, Ethiopia. Environmental Systems Research, 5(1), 1-8. https://doi.org/10.1186/s40068-015-0046-x

Bedeke, S., Vanhove, W., Gezahegn, M., Natarajan, K., \& Van Damme, P. (2019). Adoption of climate change adaptation strategies by maize-dependent smallholders in Ethiopia. NJAS-Wageningen Journal of Life Sciences, 88, 96-104. https://doi.org/10.1016/j.njas.2018.09.001

Belay, A., Recha, J. W., Woldeamanuel, T., \& Morton, J. F. (2017). Smallholder farmers' adaptation to climate change and determinants of their adaptation decisions in the Central Rift Valley of Ethiopia. Agriculture \& Food Security, 6(1), 1-13. https://doi.org/10.1186/s40066-017-0100-1

Bigger, P., \& Webber, S. (2021). Green structural adjustment in the World Bank's resilient city. Annals of the American Association of Geographers, 111(1), 36-51. https://doi.org/10.1080/24694452.2020.1749023

Bryan, E., Deressa, T. T., Gbetibouo, G. A., \& Ringler, C. (2009). Adaptation to climate change in Ethiopia and South Africa: options and constraints. Environmental science \& policy, 12(4), 413-426. https://doi.org/10.1016/j.envsci.2008.11.002

Carter, T. R. (1996). Assessing climate change adaptations: the IPCC guidelines. In Adapting to Climate Change (pp. 27-43). Springer, New York, NY. https://doi.org/10.1007/978-1-4613-8471-7_4

Deressa, T. T., Hassan, R. M., Ringler, C., Alemu, T., \& Yesuf, M. (2009). Determinants of farmers' choice of adaptation methods to climate change in the Nile Basin of Ethiopia. Global environmental change, 19(2), 248-255. https://doi.org/10.1016/j.gloenvcha.2009.01.002

El Bilali, H., Bassole, I. H. N., Dambo, L., \& Berjan, S. (2020). Climate change and food security. Poljoprivreda $i$ Sumarstvo, 66(3), 197-210. https://doi.org/10.17707/AgricultForest.66.3.16

Feleke, F. B., Berhe, M., Gebru, G., \& Hoag, D. (2016). Determinants of adaptation choices to climate change by sheep 
and goat farmers in Northern Ethiopia: the case of Southern and Central Tigray, Ethiopia. SpringerPlus, 5(1), 1-15. https://doi.org/10.1186/s40064-016-3042-3

Gebreegziabher Z., Mekonnen A., \& Seyoum A. (2012). Carbon Markets and Mitigation strategies for Africa/Ethiopia: Litereture Review and the way forward: EDRI research report 14.

Greene, W. H. (2003). Econometric analysis. Fifth edition. Prentice Hall, New Jersey.

Gujarati, D. N. (1995). Basic Econometrics. Second Edition. New York: McGraw Hill Inc.

Juana, J. S., Kahaka, Z., \& Okurut, F. N. (2013). Farmers' perceptions and adaptations to climate change in sub-Sahara Africa: A synthesis of empirical studies and implications for public policy in African agriculture. Journal of Agricultural Science, 5(4), 121. https://doi.org/10.5539/jas.v5n4p121

Kassie, M., Zikhali, P., Manjur, K., \& Edwards, S. (2009, August). Adoption of sustainable agriculture practices: Evidence from a semi-arid region of Ethiopia. In Natural Resources Forum (Vol. 33, No. 3, pp. 189-198). Oxford, UK: Blackwell Publishing Ltd. https://doi.org/10.1111/j.1477-8947.2009.01224.x

Molotoks, A., Smith, P., \& Dawson, T. P. (2021). Impacts of land use, population, and climate change on global food security. Food and Energy Security, 10(1), e261. https://doi.org/10.1002/fes3.261

Ndambiri, H. K., Ritho, C. N., \& Mbogoh, S. G. (2013). An evaluation of farmers' perceptions of and adaptation to the effects of climate change in Kenya.

Ndambiri, H. K., Ritho, C., Mbogoh, S. G., Nyangweso, P. M., Ng'ang'a, S. I., Muiruri, E. J., ... \& Omboto, P. I. (2012). Analysis of farmers' perceptions of the effects of climate change in Kenya: the case of Kyuso district (No. 304-2016-4806, pp. 309-328).

Ojo, T., \& Baiyegunhi, L. (2018). Determinants of adaptation strategies to climate change among rice farmers in Southwestern Nigeria: a multivariate probit approach.

Omer, A. A. (2019). Adoption of climate smart agricultural technologies and determinants choice of adaptation strategies to climate variability in midhega tola district, eastern ethiopia. Assessment.

Sani, S., Haji, J., \& Goshu, D. (2016). Climate change adaptation strategies of smallholder farmers: The case of Assosa District, Western Ethiopia. J. Environ. Earth Sci, 6(7), 1-15.

Tesfaye, W., \& Seifu, L. (2016). Climate change perception and choice of adaptation strategies: Empirical evidence from smallholder farmers in east Ethiopia. International Journal of Climate Change Strategies and Management. https://doi.org/10.1108/IJCCSM-01-2014-0017

Tesso, G., Emana, B., \& Ketema, M. (2012). Analysis of vulnerability and resilience to climate change induced shocks in North Shewa, Ethiopia. Agricultural Sciences, 3(06), 871. https://doi.org/10.4236/as.2012.36106

Yenealem, K., Fekadu, B., Jema, H., \& Belaineh, L. (2013). Farmers' perception of the impact of land degradation and soil and water conservation measures in West Harerghe Zone of Oromia National Regional State, Ethiopia. Journal of Biology, Agriculture and Healthcare, 3(11), 12-18.

Zizinga, A., Kangalawe, R. Y., Ainslie, A., Tenywa, M. M., Majaliwa, J., Saronga, N. J., \& Amoako, E. E. (2017). Analysis of farmer's choices for climate change adaptation practices in South-Western Uganda, 1980-2009. Climate, 5(4), 89. https://doi.org/10.3390/cli5040089

Zougmoré, R. B., Läderach, P., \& Campbell, B. M. (2021). Transforming Food Systems in Africa under Climate Change Pressure: Role of Climate-Smart Agriculture. Sustainability, 13(8), 4305. https://doi.org/10.3390/su13084305

\section{Copyrights}

Copyright for this article is retained by the author(s), with first publication rights granted to the journal.

This is an open-access article distributed under the terms and conditions of the Creative Commons Attribution license which permits unrestricted use, distribution, and reproduction in any medium, provided the original work is properly cited. 